Received: 1 June 2019

Revision received: 8 July 2019

Copyright $\odot 2019$ ESTP

Accepted: 10 July 2019

www.estp.com

DOI 10.12738/estp.2019.3.002 • July $2019 \cdot 19(3) \cdot 14-32$

Article

\title{
Can Information and Communication Technology Improve College Access for All in the United States of America?
}

\author{
Sunha Kim \\ University at Buffalo, USA
}

\author{
Mary McVee \\ University at Buffalo, USA
}

\author{
Myles S. Faith \\ University at Buffalo, USA
}

\begin{abstract}
In response to the increasing importance of a college education, this study investigates the college access trajectories of targeted racial and linguistic minority students and recommends ways to promote their college access. High school completers drawn from the U.S. National Center for Education Statistics were tracked for eight years, and a series of discrete-time survival analyses was conducted. The results revealed significantly lower college access rates for racial and linguistic minority students than for comparable White English-speaking students. Information and Communication Technology (ICT) access and ICT use for educational purposes were identified as potential ways to support college access for racial and linguistic minority students.
\end{abstract}

\section{Keywords}

College access $\bullet$ Race/Ethnicity $\bullet$ Linguistic status $\bullet$ Minority students $\bullet$ ICT $\bullet$ Survival analysis

We would like to acknowledge the support by the Growing Research Opportunities-Working in Teams (GROW-IT) Initiative led by Dr. Gregory A. Fabiano, Associate Dean for Interdisciplinary Research, in the Graduate School of Education (GSE) at the State University of New York at Buffalo.

Correspondence to Sunha Kim, PhD, Assistant Professor, Department of Counselling, School, \& Educational Psychology, State University of New York at Buffalo. 423 Baldy Hall, Buffalo, 14260-1000, New York. Email: sunhakim@buffalo.edu

Citation: Kim, S., McVee, M., \& Faith, M. S. (2019). Can information and communication technology improve college access for all in United States of America? Educational Sciences: Theory \& Practice, 19(3), 14 - 32. http://dx.doi.org/10.12738/estp.2019.3.002 
Given the importance of postsecondary education, college access and equity have been critical policy considerations in recent years. A college-education is essential to today's competitive global economy (Barra \& Zotti, 2017; Waryoba, 2017). Without a college degree, it has become increasingly challenging to obtain a good-paying career (Brannelly, Lewis, \& Ndaruhutse, 2011; Carnevale, Smith, \& Strohl, 2013; Kenayathulla, 2013). Postsecondary education remains one of the most influential factors determining future earning power (Lavrinovicha, Lavrinenko, \& Teivans-Treinovskis, 2015; Smythe, 2019), and individuals with college degrees report lifetime earnings one million U.S. dollars more than those only with high school diplomas (Barrow, Brock, \& Rouse, 2013). Beyond these financial aspects, there are social and community benefits since college graduates tend to have better physical and psychological health, engage more in educational activities with their children, and take on more volunteer work compared with high school graduates (Ma, Pender, \& Welch, 2016).

Recognizing the important role of postsecondary education, there has been a national drive to improve the college access rate for young people in America, with President Obama emphasizing increased access to college for American youths as one of his important education agenda items (White House Press Secretary Fact Sheet, 2010). Efforts to improve the college access rate seem to be achieving some success given the tremendous growth of higher education in the United States in recent years. According to national data from the US government, approximately 19.8 million students were attending postsecondary degree granting institutions as of fall 2016 (Snyder, de Brey, \& Dillow, 2019). The number of students enrolled in college was 24\% higher in 2006 than in 1996 and increased by a further 12\% between 2006 and 2016.

However, a closer examination of college participation rates reveals that some student subgroups still suffer from a noticeably lower rate of college enrollment. For instance, although $66 \%$ of Caucasian high school graduates went on to attend college in 2016, only 51\% of Afro-American students and 59\% of Hispanic students did so (Cahalan, Perna, Yamashita, Wright, \& Santillan, 2018). In addition to these racial disparities, another gap exists across the different linguistic groups. This is becoming increasingly important because as of 2015, more than 4.7 million English Language Learners (ELL) were enrolled in public elementary and secondary schools (Snyder et al., 2019). Educators need to pay urgent attention to the comparatively lower college access rate of these ELL students (Johnson, 2019; Kanno \& Cromley, 2013). To address these racial/linguistic disparities, in this study we sought to investigate college access trajectories of students from various racial and linguistic groups.

We began by identifying three types of Information and Communications Technology (ICT) variables (i.e., Internet access at home, computer use for school work, computer use for learning on their own) as potential interventions to improve college access for diverse students, with a specific focus on positive outcomes due to Internet access and computer use for learning. The Internet and computers were targeted ICT due to their widespread availability among young people (Organization for Economic Cooperation and Development [OECD], 2017). Internet access and computer use have also been shown to have positive effects on other types of academic attainments (e.g., mathematics and science achievement; high school completion) for educationally disadvantaged students from diverse racial and linguistic groups (Kim, 2018a; 2018b; Kim, Chang, Singh, \& Allen, 2015). Educationally marginalized students are often first-generation college students, and without college-educated family members to guide them, the students often fail to obtain information essential for college application (Engle, 2007). While the Internet does not resolve this problem, it could provide the inexhaustible access to critical college information and resources (Wohn, Ellison, Khan, Fewins-Bliss, \& Gray, 2013). Using computers for learning can also help educationally marginalized students to acquire the technology knowledge and skills that they will need to successfully utilize the online college information they acquire via ICT access (Eynon \& Malmberg, 2011). 
In particular, ICT use for autonomous learning might also be helpful for educationally marginalized students without experienced guides in their families who can help them successfully complete the online college application process (Venegas, 2006; Sumuer, 2018).

To empirically explore the association of three ICT variables with college access, we applied survival analyses to data extracted from the Educational Longitudinal Study (ELS), a U.S. nationally representative dataset from the National Center for Education Statistics (NCES). Survival analysis is an advanced statistics analysis technique that is used to investigate categorical outcome variables (in this case, college access vs. no access) measured over time (Singer \& Willett, 2003).

The main objective of this study was to answer the following research questions: (i) Do students from diverse racial and linguistic groups in the United States exhibit differences in college access? What is the trend of the college access trajectory for these diverse students? (ii) The selected variables (such as internet access, computer use for schoolwork, computer use for autonomous learning) are associated with college access probability for students from diverse racial and linguistic groups?

\section{College Access}

Ever since the 1970s, the overall trend in the number of undergraduates enrolled in degree-granting institutions has been upward, revealing the growth in this sector over time (Cahalan et al., 2018). In less than three decades, college enrollment in the United States rose from around 26\% in 1980 to approximately 40\% (Aud, Fox, \& Kewal Ramani, 2010). However, despite this growth, the U. S. are not yet free from college access issues. This statement can be partly supported by an international comparison. According to a report entitled Education at a Glance (OECD, 2017), the U. S. is experiencing a slower increase in the attainment rate of college degrees than their international peers, declining from $2^{\text {nd }}$ among 30 countries in 2000 , with an attainment rate of $30 \%$, to $18^{\text {th }}$ among 37 countries in 2017 an attainment rate of $37 \%$.

Within the United States, the racial gap in college enrollment, a critical initial step towards college degree attainment has been a grave concern for some time (Perna, 2015). In 1976, out of high school graduates, African (Afro)-American (33\%) and Hispanic (34\%) students demonstrated lower college enrollment rates when compared with White students $(41 \%)$, and unfortunately, this racial gap has not narrowed since 1976 (Cahalan at el., 2018). For this study, we also considered another gap, the college access problem for ELL students. Out of ELL high school students, less than $70 \%$ of students completed high school on time as compared to all US students where $84 \%$ of students completed high school on time. Fewer than $55 \%$ of ELL high school students went on to colleges, compared to more than $75 \%$ of native English speakers (Johnson, 2019; Kanno \& Cromley, 2013).

\section{College and Internet Access}

In order to access college successfully, students need to be informed of appropriate college preparation and what their choices will be, and provided with essential resources related to the college preparation and enrollment process (Akerhielm, Berger, Hooker, \& Wise, 1998; Tierney \& Jun, 2001). Regrettably, despite the importance of obtaining this critical college information and the related resources, educationally marginalized students have often encountered a number of challenges that prevent them from obtaining the essential information and resources. For example, many educationally marginalized students suffer from a lack of college advice or guidance in the college enrollment process at home if they lack college-educated parents or siblings (Engle, 2007; Martinez \& Welton, 2014; Vega, Moore III, \& Miranda, 2015). 
Also, their schools often fail to supply their parents with the crucial resources needed to help them to guide their children through the college application process with school personnel acting as gatekeepers to college access (Martinez, Cortez, \& Saenz, 2013; Martinez, Vega, \& Marquez, 2019). As more and more higher education institutions have distributed pre-college and application information via their institutional websites on the Internet, when asking for online applications, even those disadvantaged students with good access to the Internet are expected to obtain college-enrollment information and resources to successfully gain college access (Daun-Barnett \& Das, 2010; Taylor, 2018).

In recent years, racial minority groups have benefitted from huge increases in Internet adoption at home (National Telecommunications and Information Administration [NTIA], 2018). As of 2017, the percentages of Afro-Americans (65.3\%) and Hispanics (64.5\%) with Internet access at home were far higher than in 1998, when only $9.2 \%$ and $8.7 \%$, respectively, had the Internet access at home. Despite this increase, however, ethnic minority groups still have lower Internet access rates than their White peers (75.2\%) as of 2017.

Additionally, students' Internet access at home is often influenced by their linguistic status according to a report by the NCES (Kewal Ramani at el., 2018). Compared with their Non-ELL peers (93\%), ELL students showed a much lower Internet access rate (82\%). Considering the potential links between the Internet and college application process (Dettling, Goodman, \& Smith, 2018), educators need to take account into the comparatively low Internet access rates among racial/linguistic minority students, as this possibly relates to their college access. In view of its potential contribution to improving college access for racial and linguistic minority students, in this study we examined Internet access status and its potential benefits for these students.

\section{Computer Use for Educational Purposes}

In addition to Internet access, this study included computer use for academic purposes as a potential medium facilitating students' transition to college. Despite the potential for ICT to have positive influences on college participation, access to ICT alone is not enough. Mere access can expose students to challenges such as those resulting from a complicated application process which involves an enormous quantity of college information. This often overwhelms students, hampering their efforts to obtain all the full information they need and/or select the correct information to support their successful college access (DaunBarnett \& Das, 2013; Klasik, 2012).

As a possible way to mitigate these issues, we speculated that previous experience with computer use for academic purposes could equip students with the digital skills they would need to evaluate and utilize online information appropriately for successful college enrollment (van Deursen \& van Dijk, 2015). Out of the various types of ICT uses, we therefore focused on computer uses, as youths tend to use computers for learning and pragmatic purposes, in contrast with their preferred usage of mobile devices, such as iPhones for recreational purposes (Mossberger, Tolbert, \& Hamilton 2012). Frequent computer use for academic purposes can help students develop digital skills and utilize ICTs to locate and evaluate the college information and choose and manipulate the necessary college information throughout the complex college application process (Lee, Tsai, Chai, \& Koh, 2014).

\section{Computer Use for Autonomous Learning}

Despite the fact that ICT has improved the accessibility and presentation of college information, educationally marginalized students and their parents often fail to benefit fully from online application processes without support from someone who can help them understand and evaluate which aspects of the 
college information are relevant/required for college admission and financial aid process (Daun-Barnett \& Das, 2013; Venegas, 2006; Fairlie \& Bahr, 2018). Minority students reported that they were very aware of this lack compared to their peers who had parents or siblings who could help them apply for college and financial aid online if asked (Brown, Wohn, \& Ellison, 2016).

Considering that many racial and linguistic minority students do not have access to college-educated guides (i.e., siblings/parents) at home, we therefore sought to investigate the potential of frequent use of computers for autonomous learning to promote students' acquisition of an adequate degree of knowledge and skills for the successful completion of the online enrollment process. For minority students without assistance from college-educated family members, more frequent use of computers for autonomous learning may provide opportunities to attain the knowledge and skills they require to exert more control over their own online college application process, which involves the identification of their own needs, the selection and the utilization of online college resources and information, and the evaluation of their own progress toward their college enrollment goals (Sumuer, 2018).

\section{Method}

\section{Participants}

This study employed longitudinal data from the Education Longitudinal Study of 2002 (ELS: 2002), a US nationally representative database from NCES. ELS: 2002 focused on the transition of young people from high school (10th grade) into postsecondary education and the workplace. ELS: 2002 started with a nationally representative cohort of high school sophomores. The sample size is about 16,000 , representing nearly 3,343,000 10th graders in 2002 in the US. In this study, we drew a subsample of 10th graders in the African (Afro)-American, Hispanic ENG, Hispanic ELL, and White groups.

The weighted total number of these students were 13,342 comprising all four racial/linguistic groups as follows: $15.1 \%$ were Afro-American students $(n=2,017), 8 \%$ were Hispanic ENG students $(n=$ $1,065), 8.1 \%$ were Hispanic ELL students $(n=1,081)$, and $68.8 \%$ were White students $(n=9,179)$. The first three of these groups were the target groups, whose low college access rate this study aimed to promote.

In this study we examined the trajectory of college access for the target groups in comparison with that of the White group, who served as a reference group. To help achieve high generalizability, this study adopted the total student weight (F3BYTSCPSWT), which addresses students' comprehensive educational experiences including their transcript data from high school to postsecondary school.

\section{Instruments}

The NCES developed and used survey instruments to measure student educational experiences by collecting the information such as student individual information (e.g., gender, race), environmental information on student home, school, and community, and student outcome information (e.g., grade, and college access). With the goal of facilitating the development of statistical analyses by researchers in the field, NCES organize and transform survey items into respective survey and composite variables. By benefitting from rich and extensive dataset of ELS, this study chose the student individual, background, and outcome variables relevant to research questions.

As main predictor variables for college access, this study used survey items on ICT variables: Internet access at home (Internet), computer use for schoolwork (ComSchool), and computer use for learning on their own (ComOwn). To represent students' Internet access, Internet access was coded 1 for 
Internet access and 0 for no access. The frequency of these two computer variables was measured on a 5point scale ranging from 1 (Never) to 5 (Every day or almost every day).

The major student outcome of interest was the college access, which this study coded as 1 for a student's college access and as 0 for no college access, by utilizing survey items on college access status from student transcript data. To measure the time to college access, this study adopted a survey item on the number of months between high school completion until first college access. This study created eight-time variables, termed $\mathrm{T}_{1}, \mathrm{~T}_{2}, \ldots, \mathrm{T}_{8}$, to denote each year necessary to build a series of discrete-time survival models, as the ELS:2002 tracked the students for eight years after their high school completion in order to measure their college access status.

In order to control for the effect of other important contextual variables on college access, this study incorporated student gender, socio-economic status (SES), and the composite score for mathematics and reading standardized tests (Math/Reading) into the survival analyses. For student gender, a gender variable was converted to a dummy variable (Male) to represent male's access status compared with female as a reference (Male=1; Female=0). SES is a composite score from the NCES, resulting from combining standardized components of parent/guardian educational level, family income, and parent/guardian occupation. Also, Math/Reading is a composite score, represents the average of the math and reading standardized scores. These ELS composite scores feature acceptable to good reliabilities (Ingels et al., 2014).

To explore the potential differences in access trajectories across the target racial and linguistic groups, this study utilized student items on racial/linguistic status from ELS and created three dummy variables, with the White group (White) as the reference group: Afro-American (Afro-American =1; Not Afro-American = 0), Hispanic ENG (Hispanic English-speaking = 1; Not Hispanic English-speaking = 0); and Hispanic ELL (Hispanic ELL = 1; Not Hispanic ELL = 0). Afro-American ELL was not included due to the sample size being too small for a valid survival analysis. To reach the conclusion with high generalizability, this study applied a relative weight that was created by dividing the weight variable by the mean of the weight for the analysis (Thomas, Heck, \& Bauer, 2005).

\section{Procedure}

As a sampling procedure for the ELS:2002, the NCES adopted a random stratified approach which sampled schools first and students within those schools, resulting into nationally representative $10^{\text {th }}$ graders. As a longitudinal study to explore students' transition from high school into college, the ELS:2002 tracked these sampled students until the year of 2012-2013, starting from the base year of 2002. In 2004, these sampled high school students were then augmented in the first follow-up study to represent high school seniors. In 2006, roughly two years after high school, the second follow-up study collected data on access to postsecondary institutions, choices of enrollment and college major, and other aspects of college experience. In 2012, approximately 8 years after high school, the third follow-up study obtained the data on college enrollment and employment trajectories, marital status, and families. Also, in 2013, postsecondary transcripts were obtained with the data on all completed courses, and student financial aids for college education.

\section{Data analysis}

This study conducted statistical analyses in three stages. For the initial stage, prior to the main survival analyses, this study obtained foundational features of the data via descriptive statistics and correlation analyses. As the main analytical method, this study utilized survival analysis as this is a suitable tool for exploring the occurrence, timing, and predictors of college access events in a longitudinal 
framework (Allison, 2010; Hosmer, Lemeshow, \& May, 2008; Singer \& Willett, 2003). This study then moved on to build a series of life tables that provided an overview of the college access trajectories of the targeted racial/linguistic groups over time. The life tables were particularly helpful in providing information on the access/no-access history and identifying the distinctive features of each of the four groups, with a year as a time unit. By plotting access probabilities and accumulated probabilities for no access, obtained from the life tables, this study also obtained a graphical representation of the college access/no-access patterns over time across the different racial/linguistic groups. Here, the access probability represents the proportion of high school graduates who accessed college during a given time period, while the no-access probability indicates an accumulated proportion of high school completers who did not access college by the end of the given time period.

In the final stage, this study built a series of discrete-time survival models following the recommendations of Singer and Willett (2003). Specifically, for the discrete-time models, this study adopted a completely general time specification featuring good model fit statistics, as this study included all eight time points (eight years) to estimate access probabilities during the eight-year study period. To answer research questions, this study constructed the following survival models: Group Model, Complete Model, White Model, Afro-American Model, Hispanic ENG Model, and Hispanic ELL Model. The Group Model explores group differences in access trajectories by including only racial/linguistic group variables, in addition to time variables, in the model. The Complete Model is the most comprehensive as it includes all the contextual variables in the Group Model to examine the effect of contextual variables on college access for the White group, while still accounting for the racial/linguistic group differences. The other four models investigate the association between the access probability and the contextual variables for each of racial/linguistic groups.

As the first of the six hazard models, this study built a simple model, the Group Model, and explored the differences it revealed in the access probabilities across the various racial/linguistic groups compared with the reference group. For the group comparisons, in addition to time variables, the Group Model included only three group variables, Afro-American, Hispanic ENG, and Hispanic ELL, with the White group as a reference, as follows:

$$
h\left(t_{\mathrm{ij}}\right)=1 / 1+\mathrm{e}^{-\{[\alpha 1 \mathrm{~T} 1 \mathrm{ij}+\alpha 2 \mathrm{~T} 2 \mathrm{ij}+\ldots .+\alpha 7 \mathrm{~T} 7 \mathrm{ij}+\alpha 8 \mathrm{~T} 8 \mathrm{ij}]+[\beta 1(\text { Afro-American }) 1 \mathrm{ij}+\beta 2(\text { HispanicENG }) 2 \mathrm{ij}+\beta 3(\text { HispanicELL }) 3 \mathrm{ij})]\}}
$$

(Equation 1)

where the intercept parameters $\alpha_{1}, \alpha_{2} \ldots, \alpha_{8}$ indicate the probability that a student will access college in a given year. The slope parameter $\beta_{1}$ indicates the difference in access probability between White and AfroAmerican students, $\beta_{2}$ indicates the difference in access probability between White and Hispanic ENG students, and $\beta_{3}$ indicates the difference in access probability between White and Hispanic ELL students.

As the second model, this study specified the Complete Model, which includes all the variables for the eight time periods, three racial/linguistic groups, and six contextual variables. Controlling for the group effects, this study attempted to examine the association between the contextual variables and the access probability of students in the White group as follows:

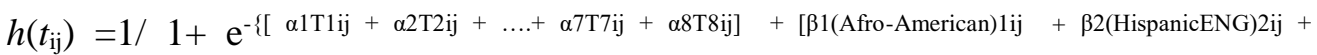
$\beta 3($ HispanicELL) $3 \mathrm{ij}+\beta 4$ (Internet) $4 \mathrm{ij}+\beta 5($ ComSchool) $5 \mathrm{ij}+\beta 6($ ComOwn $) 6 \mathrm{ij}+\beta 7($ Gender) $7 \mathrm{ij}+\beta 8$ (SES) $8 \mathrm{ij}+\beta 9$ (MathReading) $9 \mathrm{ij}]\}$

(Equation 2)

where $\beta_{4}$ indicates the effect of Internet access on access probability for a White student; $\beta_{5}$ indicates the effect of computer use for school work on access probability for a White student; $\beta_{6}$ indicates the effect of 
computer use to learn on their own on access probability for a White student; $\beta_{7}$ indicates the effect of student gender on access probability for a White student; $\beta_{8}$ indicates the effect of SES on access probability for a White student; and $\beta_{9}$ indicates the effect of composite score for Math and Reading standardized tests on access probability for a White student. The other parameters represent the same variables as in Equation 1.

In order to investigate the effects of contextual variables for each of the four racial/linguistic groups, this study constructed the final four models (White Model, Afro-American Model, Hispanic ENG Model, and Hispanic ELL Model) by separating the data for each individual group in turn. For example, in the case of the Afro-American Model, this study applied the survival analysis only to Afro-American students, thus reviewing the association between the access probability of Afro-American students with Internet access, computer use for school work, computer use to learn on their own, student gender, SES, and the composite score for math and reading tests. The equation for the last four models is as below:

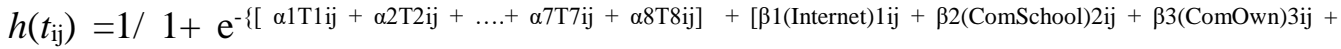

$$
\begin{aligned}
& \beta 4(\text { Gender) } 4 \mathrm{ij}+\beta 5 \text { (SES) } 5 \mathrm{ij}+\beta 6 \text { (MathReading) } 6 \mathrm{ij}]\}
\end{aligned}
$$

(Equation 3)

\section{Results}

\section{Preliminary Analyses}

Prior to running the main survival analyses, this study examined the fundamental features of the data by running a series of descriptive and correlation analyses. Table 1 displays the college access rates of these four racial/linguistic groups. Overall, higher proportions of White (88.1\%) and Afro-American students (87.2\%) tended to access college than Hispanic students (84.8\% of Hispanic ENG group, 84.4\% of Hispanic ELL group).

Table 1. College access rates of racial/linguistic and gender groups

\begin{tabular}{cccccccc}
\hline Group & Access & No Access & Subtotal & Group & Access & No Access & Subtotal \\
\hline White & 8,085 & 1,094 & 9,179 & Female & 6,518 & 633 & 7,151 \\
& $(88.1 \%)$ & $(11.9 \%)$ & & & $(91.1 \%)$ & $(8.9 \%)$ & \\
Afro-American & 1,758 & 259 & 2,017 & Male & 5,692 & 1,089 & 6,781 \\
& $(87.2 \%)$ & $(12.8 \%)$ & & & $(83.9 \%)$ & $(16.1 \%)$ & \\
Hispanic ENG & 903 & 162 & 1,065 & & & & \\
& $(84.8 \%)$ & $(15.2 \%)$ & & & & & \\
Hispanic ELL & 912 & 169 & 1,081 & & & & \\
& $(84.4 \%)$ & $(15.6 \%)$ & & & & & \\
\hline Total & 11,658 & 1,684 & 13,342 & Total & 1,722 & 12,210 & 13,932 \\
\hline
\end{tabular}

This study explored the relationships among the variables of this study using correlation analyses, as shown in Table 2. All the contextual variables exhibited significant correlations with college access. Internet access and two computer variables had a positive relationship with college access. When students had access to the Internet at home, they tended to access college more $(r=.17, p<.01)$. When students used computers for schoolwork $(r=.19, p<.01)$ or to learn on their own $(r=.10, p<.01)$ more frequently, they were again more likely to access college. The male variable showed a significantly negative correlation with college access, with male students displaying lower access rates than female students $(r=-.11, p<$ 
.01). Students' SES levels and their composite scores for math and reading tests both showed positive correlations with college access, with higher SES levels $(r=.21, p<.01)$ and higher scores $(r=.26, p<$ $.01)$ being associated with a higher likelihood of college access.

Table 2. Bivariate correlation among the studied variables

\begin{tabular}{|c|c|c|c|c|c|}
\hline & Access & ComSchool & ComOwn & SES & MathReading \\
\hline Access & & $.19^{* *}$ & $.10^{* *}$ & $.21^{* *}$ & $.26^{* *}$ \\
\hline White & $.02 * *$ & $.02^{* *}$ & $-.01^{* *}$ & $.22^{* *}$ & $.37^{* *}$ \\
\hline Afro-American & $-.01^{* *}$ & $-.03^{* *}$ & $-.02^{* *}$ & $-.15^{* *}$ & $-.28^{* *}$ \\
\hline Hispanic ENG & $-.03^{* *}$ & $-.03^{* *}$ & $.00^{*}$ & $-.08^{* * *}$ & $-.11^{* *}$ \\
\hline Hispanic ELL & $-.03^{* *}$ & $-.03^{* *}$ & $-.01^{* *}$ & $-.16^{* * *}$ & $-.21^{* *}$ \\
\hline Internet & $.17^{* *}$ & $.10^{* *}$ & $.11^{* * *}$ & $.27^{* *}$ & $.27^{* *}$ \\
\hline ComSchool & $.19^{* *}$ & & $.39^{* *}$ & $.20^{* *}$ & $.25^{* *}$ \\
\hline ComOwn & $.10^{* *}$ & $.39^{* *}$ & & $.15^{* *}$ & $.17^{* *}$ \\
\hline Male & $-.11^{* * *}$ & $-.15^{* *}$ & $.13^{* *}$ & $.03^{* *}$ & $.00^{* *}$ \\
\hline SES & $.21^{* *}$ & $.20^{* *}$ & $.15^{* *}$ & & $.40^{* *}$ \\
\hline MathReading & $.26^{* *}$ & $.25^{* *}$ & $.17^{* *}$ & $.40^{* *}$ & \\
\hline
\end{tabular}

Note: $* p<.05 ; * * p<.01$;

SES = socio-economic status; ComSchool = computer use for schoolwork; ComOwn = computer use for learning on their own; Math $/$ Reading $=$ mathematics and reading.

This study also examined the means and frequencies of contextual variables across the four racial/linguistic groups. Table 3 reveals notable differences in Internet access, SES, and the composite score for mathematics and reading tests across different groups. While $87.8 \%$ of White students had the Internet at home, a smaller proportion of other groups had Internet access (64.6\% of Afro-American, $72.7 \%$ of Hispanic ENG, and $60.3 \%$ of Hispanic ELL) and compared with White students $(M=0.22)$, other students had lower SES levels $\left(M_{\text {(Afro-American) }}=-0.09 ; M_{\text {(Hispanic ENG) }}=-0.05\right.$; and $\left.M_{\text {(Hispanic ELL) }}=-0.28\right)$. A similar pattern was detected in math and reading scores, with White students $(M=53.34)$ scoring better than the other student groups $\left(M_{\text {(Afro-American) }}=43.83 ; M_{\text {(Hispanic ENG) }}=46.88\right.$; and $\left.M_{\text {(Hispanic ELL) }}=43.52\right)$. White students $(M=2.60)$ also had a tendency to use computers for schoolwork slightly more frequently than other groups $\left(M_{\text {(Afro-American) }}=2.52 ; M_{\text {(Hispanic ENG) }}=2.50\right.$; and $\left.M_{\text {(Hispanic ELL) }}=2.48\right)$, although there was not much difference in the frequency of using computers to learn on their own across these groups ( $M_{\text {(White) }}=2.46 ; M_{\text {(Afro-American) }}$ $=2.42 ; M_{\text {(Hispanic ENG) }}=2.47$; and $M_{\text {(Hispanic ELL) }}=2.42$ ).

Table 3. Frequencies and means (standard deviation)

\begin{tabular}{|c|c|c|c|c|}
\hline & White & Afro-American & Hispanic ENG & Hispanic ELL \\
\hline \multicolumn{5}{|l|}{ Frequency (\%) } \\
\hline No Internet Access & $1,061(12.2 \%)$ & $600(35.4 \%)$ & $262(27.3 \%)$ & $382(39.7 \%)$ \\
\hline Internet Access & $7,606(87.8 \%)$ & $1,097(64.6 \%)$ & $696(72.7 \%)$ & $581(60.3 \%)$ \\
\hline \multicolumn{5}{|l|}{ Means $(S D)$} \\
\hline ComSchool & $2.60(0.93)$ & $2.52(0.94)$ & $2.50(0.93)$ & $2.48(0.91)$ \\
\hline ComOwn & $2.46(1.04)$ & $2.42(1.07)$ & $2.47(1.07)$ & $2.42(1.00)$ \\
\hline SES & $0.22(0.62)$ & $-0.09(.56)$ & $-0.05(0.55)$ & $-0.28(0.58)$ \\
\hline MathReading & $53.34(9.24)$ & $43.83(8.29)$ & $46.88(9.23)$ & $43.52(9.43)$ \\
\hline
\end{tabular}

Note: ComSchool = computer use for schoolwork; ComOwn = computer use for learning on their own; SES = socio-economic status; Math $/$ Reading $=$ mathematics and reading . 


\section{College Access Trajectories Using the Life Table Method}

This study adopted the Life Table Method to investigate the trajectories of the access/no-access probabilities. As shown in Table 4, students displayed the highest access probability in the first year $\left(h\left(t_{1}\right)\right.$ $=.71)$, after which the access probabilities fell dramatically, starting from the second year $\left(h\left(t_{2}\right)=.12\right)$ and stayed low throughout the last six years $\left(h\left(t_{3}\right)=.06, h\left(t_{4}\right)=.05, h\left(t_{5}\right)=.05, h\left(t_{6}\right)=.05, h\left(t_{7}\right)=.05\right.$, and $h\left(t_{8}\right)$ $=.06)$. Overall, the four groups displayed a very similar pattern, with a peak in the first year and then decreasing over time, although there were some group-specific features. In the first year, White students $\left(h\left(t_{1}\right)=.74\right)$ revealed a notably higher probability than the other groups: Afro-American $\left(h\left(t_{1}\right)=.63\right)$, Hispanic ENG $\left(h\left(t_{1}\right)=.61\right)$, and Hispanic ELL $\left(h\left(t_{1}\right)=.59\right)$. Afro-American students demonstrated relatively high probabilities in the last four years, with a particularly high probability in the final year $\left(h\left(t_{8}\right)=\right.$ .10) compared to all the other groups: White $\left(h\left(t_{1}\right)=.05\right)$, Hispanic ENG $\left(h\left(t_{1}\right)=.06\right)$, and Hispanic ELL $\left(h\left(t_{1}\right)=.04\right)$. Compared with the White and Afro-American students, Hispanic students showed lower probabilities over time, albeit with some exceptions in certain time periods (for example, Hispanic ENG, $\left.h\left(t_{2}\right)=.16\right)$. Most notably, Hispanic ELL students displayed the lowest probabilities for every year except the fourth year.

To present accessing pattern over the time graphically, this study plotted the access probabilities for the four racial/linguistic groups (Figure 1), which confirmed the above-mentioned similar pattern for all groups of the access probability peaking in the first year and then declining over time. Many students accessed college in the first year but then the numbers decreased from the second year onwards, with much smaller numbers of students accessing college in the last six years, with the sole exception of Afro-American students in the final year

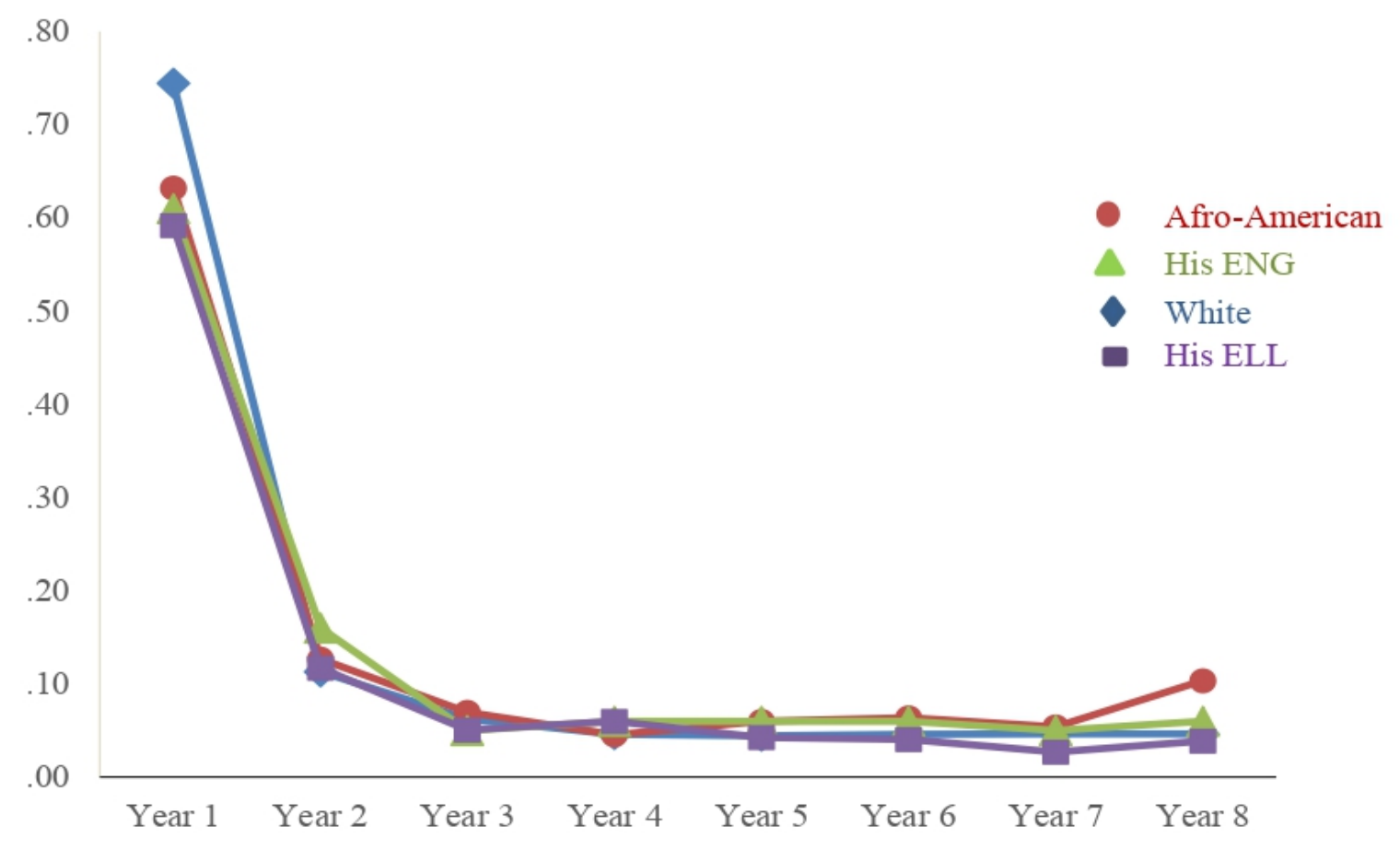

Figure 1. Estimated hazard probabilities for college access of racial/linguistic groups 
To promote understanding of college access patterns further, this study included the cumulative probabilities of no-access (no-access probabilities) in Table 4. No-access probability represents the cumulative proportion of students who had not yet accessed college up to a given year. At the beginning of the study, none of students had accessed college $\left(S\left(t_{0}\right)=1\right)$, then in the first year the no-access probabilities dropped dramatically (All, $S\left(t_{1}\right)=.30$ ) as many students accessed college in the first year.

Out of the four groups, White students showed the lowest no-access probability in the first year $\left(S\left(t_{1}\right)=.26\right)$, as their access probability was the highest in that year, and the no-access probability for Hispanic ELL was the highest $\left(S\left(t_{1}\right)=.41\right)$, as their access probabilities were lower than those of the other groups. Cumulatively, around $17 \%$ of White students did not access college for eight years after they completed high school $\left(S\left(t_{8}\right)=.17\right)$, with higher proportions of students from other groups also failing to access college at any point: $21 \%$ of Afro-American $\left(S\left(t_{8}\right)=.21\right), 23 \%$ of Hispanic ENG $\left(S\left(t_{8}\right)=.23\right)$, and $28 \%$ of Hispanic ELL students $\left(S\left(t_{8}\right)=.28\right)$. Figure 2 confirms this pattern of no-access probabilities for the four groups over time.

\section{Group Comparison Model for the Discrete-Time Survival Analysis}

As shown in Table 5, this study explored group differences in college access rate by performing a discrete survival analysis that included only the time and group variables. This study detected significant differences in college access between the target groups and the White group. Students from the AfroAmerican, Hispanic ENG and Hispanic ELL groups were less likely to access college compared with their White peers. Compared to the White group, the likelihood of accessing college for the Afro-American group was $38 \%$ lower $\left(e^{\text {(Afro-American })}=0.62, p<.01\right)$, for the Hispanic ENG group it was $31 \%$ lower $\left(e^{(\text {HsipanicENG })}=\right.$ $0.69, p<.01)$, and for the Hispanic ELL group it was $25 \%$ lower $\left(e^{\text {(HispanicELL })}=0.75, p<.01\right)$.

\section{Complete Model of Discrete Survival Analysis}

This study performed another discrete survival analysis to investigate which contextual factors were associated with the college access probability of White students after controlling for group differences. As the data presented in Table 5 demonstrate, the Complete Model revealed that students' college access was significantly associated with the following student factors: student access to the Internet at home, computer use for schoolwork, being male, SES and the composite score for math and reading.

Internet access and more frequent use of computers for schoolwork were associated with a higher chance of accessing college $\left(e^{(\text {Internet })}=1.34, p<.01 ; e^{(\text {Comschool })}=1.31, p<.01\right.$, respectively $)$, while the access probability of male students was lower than that of their female peers $\left(e^{(\text {Male })}=0.75, p<.01\right)$. Higher SES and a higher composite score for math and reading were both associated with a higher likelihood of accessing college $\left(e^{(\mathrm{SES})}=1.60, p<.01 ; e^{(\text {MthReading })}=1.03, p<.01\right.$, respectively $)$.

\section{Ethnic/Linguistic Models of Discrete Survival Analysis}

Finally, this study conducted a series of discrete survival analyses to investigate the effects of the various contextual factors among the four different groups in order to gain a clear understanding of the direct effect of these contextual factors, building on the indirect interpretations obtained from the comparisons with the reference group. This study explored the effects of the factors for each of four groups simultaneously by separating the data for each group and constructing four models for White students (White Model), Afro-American students (Afro-American Model), Hispanic ENG students (Hispanic ENG Model), and Hispanic students (Hispanic ELL Model). The results are displayed in Table 5. 
Table 4. Estimated access and no-access probabilities using life table method

\begin{tabular}{lclccc}
\hline & \multicolumn{5}{c}{ Estimated Access Probability } \\
\cline { 3 - 6 } Year & All & White & Afro-American & Hispanic ENG & Hispanic ELL \\
\hline 1 & 0.71 & 0.74 & 0.63 & 0.61 & 0.59 \\
2 & 0.12 & 0.11 & 0.13 & 0.16 & 0.12 \\
3 & 0.06 & 0.06 & 0.07 & 0.05 & 0.05 \\
4 & 0.05 & 0.05 & 0.05 & 0.06 & 0.06 \\
5 & 0.05 & 0.04 & 0.06 & 0.06 & 0.04 \\
6 & 0.05 & 0.04 & 0.06 & 0.06 & 0.04 \\
7 & 0.05 & 0.05 & 0.05 & 0.05 & 0.03 \\
8 & 0.06 & 0.05 & 0.10 & 0.06 & 0.04 \\
\hline & & \multicolumn{5}{c}{ Estimated No-Access Probability } \\
\hline & All & White & Afro-American & Hispanic ENG & Hispanic ELL \\
\hline 0 & 1.00 & 1.00 & 1.00 & 0.00 & 1.00 \\
1 & 0.30 & 0.26 & 0.37 & 0.33 & 0.41 \\
2 & 0.26 & 0.23 & 0.32 & 0.31 & 0.36 \\
3 & 0.24 & 0.21 & 0.30 & 0.27 & 0.34 \\
4 & 0.23 & 0.20 & 0.29 & 0.26 & 0.31 \\
5 & 0.22 & 0.19 & 0.27 & 0.25 & 0.30 \\
6 & 0.21 & 0.19 & 0.25 & 0.23 & 0.29 \\
7 & 0.20 & 0.18 & 0.24 & 0.21 & \\
8 & 0.19 & 0.17 & \multicolumn{5}{c}{}
\end{tabular}

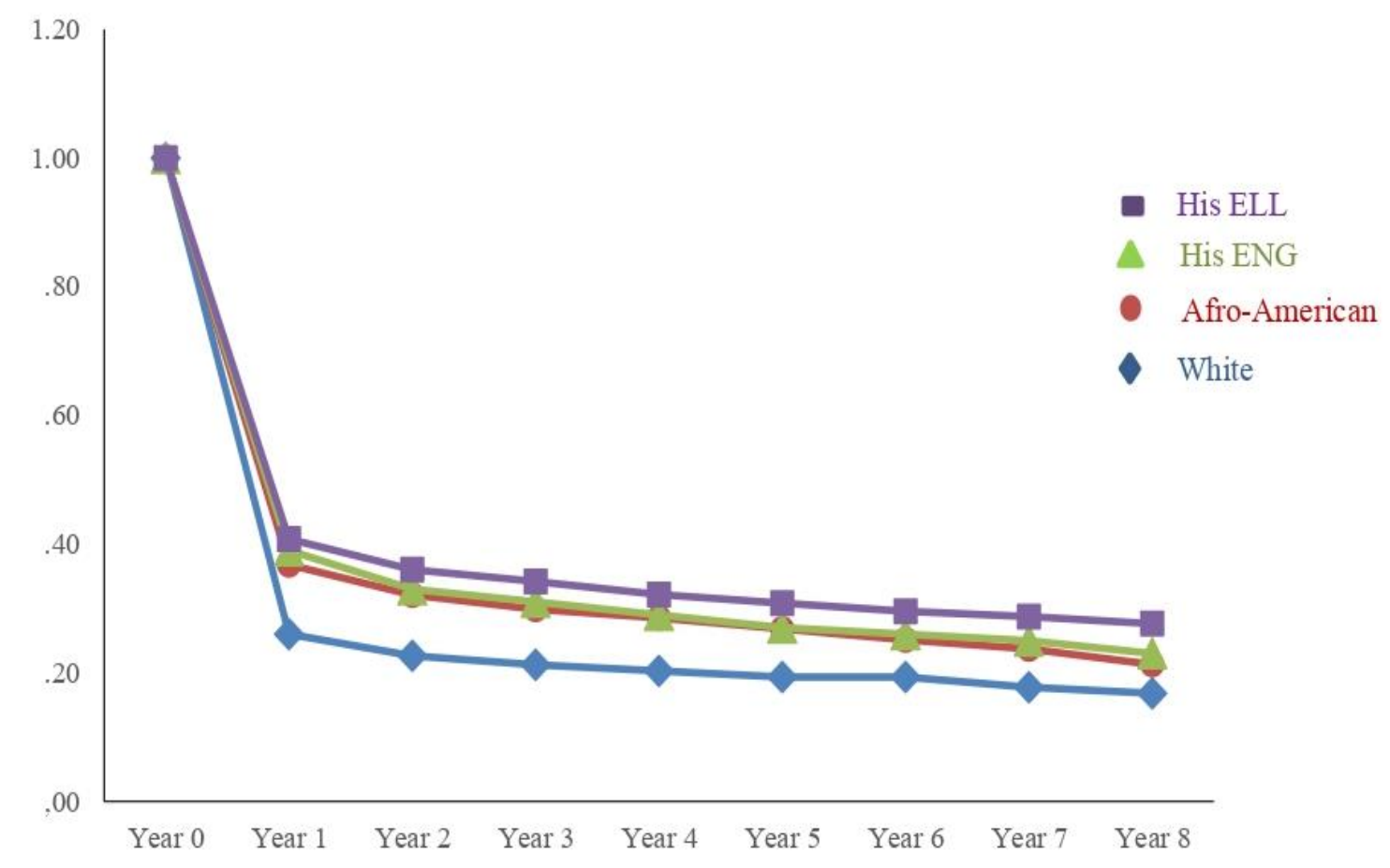

Figure 2. Estimated survival probabilities for college access of racial/linguistic groups 
Table 5. Analysis results from discrete survival models

\begin{tabular}{|c|c|c|c|c|c|c|c|c|c|c|c|c|}
\hline & \multicolumn{2}{|c|}{ Group Model } & \multicolumn{2}{|c|}{ Complete Model } & \multicolumn{2}{|c|}{ White Model } & \multicolumn{2}{|c|}{$\begin{array}{c}\text { Afro-American } \\
\text { Model }\end{array}$} & \multicolumn{2}{|c|}{$\begin{array}{c}\text { Hispanic ENG } \\
\text { Model }\end{array}$} & \multicolumn{2}{|c|}{$\begin{array}{c}\text { Hispanic ELL } \\
\text { Model }\end{array}$} \\
\hline & $\beta(S E)$ & $\mathrm{e}^{\beta}$ & $\beta(S E)$ & $\mathrm{e}^{\beta}$ & $\beta(S E)$ & $\mathrm{e}^{\beta}$ & $\beta(S E)$ & $\mathrm{e}^{\beta}$ & $\beta(S E)$ & $\mathrm{e}^{\beta}$ & $\beta(S E)$ & $\mathrm{e}^{\beta}$ \\
\hline Afro-American & $\begin{array}{l}-.48 * * \\
(.004)\end{array}$ & 0.62 & $\begin{array}{l}-.03 * * \\
(.007)\end{array}$ & 0.97 & & & & & & & & \\
\hline Hispanic ENG & $\begin{array}{l}-.37 * * \\
(.005)\end{array}$ & 0.69 & $\begin{array}{l}-.18 * * \\
(.008)\end{array}$ & 0.84 & & & & & & & & \\
\hline Hispanic ELL & $\begin{array}{l}-.28 * * \\
(.005)\end{array}$ & 0.75 & $\begin{array}{l}.44 * * \\
(.011)\end{array}$ & 1.55 & & & & & & & & \\
\hline Internet & & & $\begin{array}{l}.29 * * \\
(.006)\end{array}$ & 1.34 & $\begin{array}{l}.23^{* *} \\
(.009)\end{array}$ & 1.26 & $\begin{array}{l}.16^{* *} \\
(.012)\end{array}$ & 1.17 & $\begin{array}{l}.72 * * \\
(.015)\end{array}$ & 2.06 & $\begin{array}{l}.31 * * \\
(.020)\end{array}$ & 1.37 \\
\hline ComSchool & & & $\begin{array}{l}.27 * * \\
(.003)\end{array}$ & 1.31 & $\begin{array}{l}.33^{* *} \\
(.003)\end{array}$ & 1.40 & $\begin{array}{l}.07 * * \\
(.007)\end{array}$ & 1.07 & $\begin{array}{l}.12 * * \\
(.009)\end{array}$ & 1.12 & $\begin{array}{c}-.02 \\
(.013)\end{array}$ & 0.98 \\
\hline ComOwn & & & $\begin{array}{c}-.00 \\
(.002)\end{array}$ & 1.00 & $\begin{array}{l}-.07 * * \\
(.003)\end{array}$ & 0.94 & $\begin{array}{l}.07 * * \\
(.006)\end{array}$ & 1.08 & $\begin{array}{l}.21 * * \\
(.007)\end{array}$ & 1.24 & $\begin{array}{l}.54 * * \\
(.011)\end{array}$ & 1.72 \\
\hline Male & & & $\begin{array}{l}-.29 * * \\
(.005)\end{array}$ & 0.75 & $\begin{array}{l}-.30 * * \\
(.006)\end{array}$ & 0.74 & $\begin{array}{l}-.21 * * \\
(.011)\end{array}$ & 0.81 & $\begin{array}{l}-.40 * * \\
(.014)\end{array}$ & 0.67 & $\begin{array}{l}-.06 * * \\
(.020)\end{array}$ & 0.94 \\
\hline SES & & & $\begin{array}{l}.47 * * \\
(.004)\end{array}$ & 1.60 & $\begin{array}{l}.51^{* *} \\
(.005)\end{array}$ & 1.67 & $\begin{array}{l}.46^{* *} \\
(.011)\end{array}$ & 1.58 & $\begin{array}{l}.43 * * \\
(.013)\end{array}$ & 1.54 & $\begin{array}{l}.09 * * \\
(.020)\end{array}$ & 1.09 \\
\hline MathReading & & & $\begin{array}{l}.03 * * \\
(.000)\end{array}$ & 1.03 & $\begin{array}{l}.04 * * \\
(.000)\end{array}$ & 1.04 & $\begin{array}{l}.04 * * \\
(.001)\end{array}$ & 1.04 & $\begin{array}{l}-.00 * * \\
(.001)\end{array}$ & 1.00 & $\begin{array}{l}.05^{* *} \\
(.001)\end{array}$ & 1.05 \\
\hline$-2 \mathrm{LL}$ & \multicolumn{2}{|c|}{3325417.14} & \multicolumn{2}{|c|}{1401028.41} & \multicolumn{2}{|c|}{923289.91} & \multicolumn{2}{|c|}{230290.52} & \multicolumn{2}{|c|}{138886.24} & \multicolumn{2}{|c|}{78409.66} \\
\hline
\end{tabular}

Note: $* p<.05 ; * * p<.01$

Internet = Internet access at home; SES = socio-economic status; ComSchool = computer use for schoolwork; ComOwn = computer use for learning on their own; Math $/$ Reading $=$ mathematics and reading. 
The White Model confirmed that all the contextual factors had a significant association with the likelihood of accessing college. White students with Internet access and/or more frequent use of computers for schoolwork were significantly more likely to access college $\left(e^{(\text {Internet })}=1.26, p<.01 ; e^{(\text {Comschool })}=1.40\right.$, $p<.01$, respectively). However, White students who used computers to learn on their own displayed a significantly lower likelihood of college access $\left(e^{(\text {Comown })}=0.94, p<.01\right)$ and male students were also significantly less likely to access college than their female counterparts $\left(e^{(\text {Male })}=0.74, p<.01\right)$. Students with a higher SES level and a higher score in math and reading displayed a significantly higher chance of college access $e^{(\mathrm{SES})}=1.67, p<.01 ; e^{(\text {MthReading })}=1.04, p<.01$, respectively).

According to the Afro-American Model, a higher chance of college access was correlated with Internet access as well as more frequent use of computers for schoolwork and computers to learn on their own among Afro-American students $\left(e^{(\text {Internet })}=1.17, p<.01 ; e^{(\text {ComSchool })}=1.07, p<.01\right.$; and $e^{(\text {ComOwn })}=1.08$, $p<.01$, respectively). Afro-American male students were less likely to access college than their female peers $\left(e^{(\text {Male })}=0.81, p<.01\right)$, but again higher SES level and a higher score for math/reading among AfroAmerican students were significantly related to a higher chance of college access $\left(e^{(\mathrm{SES})}=1.58, p<.01\right.$; and $e^{\text {(MthReading) }}=1.04, p<.01$, respectively).

As shown in the Hispanic ENG Model, Hispanic ENG students tended to access college significantly more when having access to the Internet $\left(e^{\text {(Internet) }}=2.06, p<.01\right)$, using computers for schoolwork $\left(e^{(\text {ComSchool })}=1.12, p<.01\right)$, and/or using computers to learn on their own $\left(e^{(\text {ComOwn })}=1.24, p<\right.$ $.01)$. Male Hispanic ENG students had a lower likelihood of college access than their female counterparts $\left(e^{(\text {Male })}=0.67, p<.01\right)$, while Hispanic ENG students who had a higher SES level were more likely to access college $\left(e^{(\mathrm{SES})}=1.54, p<.01\right)$. Surprisingly, after controlling for all other variables Hispanic ENG students who scored higher in math and reading tests demonstrated a lower likelihood of accessing college $\left(e^{\text {(MthReading) }}=1.00, p<.01\right)$.

The Hispanic ELL Model revealed that Internet access and more frequent use of computers to learn on their own had a statistically significant association with the likelihood of access among Hispanic ELL students $\left(e^{(\text {Internet })}=1.37, p<.01 ; e^{(\text {ComOwn })}=1.72, p<.01\right.$, respectively $)$. However, computer use for schoolwork had a significant association with access likelihood among Hispanic ELL students. As in the other groups, Hispanic ELL male students exhibited a significantly lower college access rate than their female peers $\left(e^{(\text {Male })}=.94, p<.01\right)$. Higher SES level and higher scores in Math and Reading tests were again significantly related to higher access among Hispanic ELL students $\left(e^{(\mathrm{SES})}=1.09, p<.01 ; e^{(\mathrm{MthReading})}\right.$ $=1.05, p<.01$, respectively).

\section{Discussion}

By conducting a series of discrete-time survival analyses, this study investigated the college access trajectories of three target racial and linguistic groups in the United States: Afro-American, Hispanic ENG, and Hispanic ELL, with White as the reference group. This study then examined the relationship between contextual variables and college access, paying attention specifically to the potential differences across racial and linguistic groups. According to the findings, compared with White high school graduates, their peers in other racial and linguistic groups showed significantly lower levels of college access. The study provides empirical evidence regarding the unequal access to college among different racial and linguistic groups in the U.S. The results revealed a pressing need for educational researchers to address college access issues from a racial and linguistic perspective that focuses particularly on students in the Afro-American, Hispanic ENG, and Hispanic ELL groups. 
The study presented college access patterns over the eight years after high school completion via a set of generic and group-specific trajectories. The general trajectories showed that the access rate peaked in the first year and then decreased over time. High school graduates tended to enter college within one year of high school graduation, with only a relatively small percentage accessing college for the first time in the following seven years. These findings support those reported by previous studies that found a negative association between college access and college postponement of one year or more (Bozick \& DeLuca, 2005; Niu \& Tienda, 2013).

Therefore, this study urges educators and parents to encourage students to transition to college directly after their high school graduation rather than delaying enrollment. The group-specific trajectories revealed a relatively higher college access rate in the eighth year among students in the Afro-American group, which suggests that some Afro-American students may have postponed their enrollment in college in order to gain work experience, then applied to obtain a college degree after those seven years (Martin, 2010). When advising Afro-American students about postsecondary education opportunities, educators and parents need to be aware of the tendency of some Afro-American students to delay college access.

As one of the important predictors for college access, this study included Internet access at home and demonstrated its significant role for all four racial and linguistic groups. This finding supports emerging empirical analyses results regarding its association with college access, extending the influence of Internet access beyond academic performance in high school, as found by existing studies (Luu \& Freeman, 2011). In spite of its importance, students in the Afro-American, Hispanic ENG, and Hispanic ELL groups were found to have lower Internet access rates compared with their White peers. In particular, students in the Hispanic ELL group showed the lowest access rate.

This finding advances the body of knowledge on the digital divide to reveal another aspect of this divide along the boundaries of racial and linguistic status beyond a simple unidimensional aspect of race or linguistic status (NTIA, 2018). Future studies on the digital divide across racial and linguistic groups might consider exploring the issue of unequal access to different types of connections (Davison \& Cotten, 2009) and devices (Pearce \& Rice, 2013) rather than focusing solely on physical access to the Internet. The unequal access to certain types of connections and devices might create additional barriers for some racial and linguistic groups in obtaining essential college information, even with physical access to the Internet.

In this study we also explored the role of computer use for educational purposes as another important predictor for college access, looking specifically at the generic and differential effects of computer use for schoolwork and for learning on their own across four racial and linguistic groups. In the case of computer use for schoolwork, a significant contribution was found on college access for all of the racial and linguistic groups except the Hispanic ELL group. In terms of using the computer to learn on their own, the study identified a significantly positive association with college access for students in the Afro-American, Hispanic ENG, and Hispanic ELL groups, narrowing the gap between these groups and the White group. These findings suggest that, for students in the Afro-American and Hispanic ENG groups, educators need to emphasize the more frequent use of computers for schoolwork and learning on their own and strongly encourage the Hispanic ELL group to use computers to learn on their own more frequently.

The positive contribution of educational computer use for specific racial and linguistic groups might be partially due to the fact that the frequent use of computers, the preferred device for navigating the web for academic/serious purposes (Mossberger, Tolbert, \& Hamilton, 2012), might have helped students in those groups gain the technology skills needed for navigating the often-complex online college application and admissions process. These findings suggest that future studies might design targeted interventions to 
help students attain college access-related digital skills (Fairlie \& Bahr, 2018) by training them to use computers to search for college information and apply for college online.

Importantly, educators need to pay special attention to the distinctive benefits of computer use to learn on their own for all the targeted racial and linguistic groups. One problem faced by many disadvantaged students who are members of racial or linguistic minorities is the lack of family members who are familiar with the complicated online application process and, thus, can help them interpret and process online college information (Brown et al., 2016). One possible reason for the pronounced benefit of computer use for learning on their own, as opposed to computer use for schoolwork, might be that frequent use for autonomous learning could have helped the targeted racial and linguistic students attain additional self-directed learning skills by using computers in a way that enabled them to apply their knowledge and skills to choose, manage, and exploit pertinent information and resources throughout all the steps of the online college application process autonomously (Rashid \& Asghar, 2016; Sumuer, 2018).

In summary, the study's findings on group-specific guidance of computer uses for educational purposes provides an empirical basis for future research that extends their potential as important factors for college access beyond academic performance in high school (Drain, Grier, \& Sun, 2012; Freeman, 2012; Kim \& Chang, 2008; Papanastasiou \& Ferdig, 2006). At the same time, it contributes to the rich body of knowledge on college access and associated factors by adding empirical evidence on Internet access and computer uses to existing factors, including college knowledge (Perna, 2006), college aspirations (Dyce, Albold, \& Long, 2013), academic preparation and achievement (Perna, 2005), and parental involvement (Horn, 1998).

In an attempt to examine access rate and associated factors properly, this study employed survival analysis, an advanced statistics methodology suitable for exploring educational phenomena with dichotomous outcomes using longitudinal data. A discrete-time survival analysis was conducted for this study, creating a series of models using a broad time metric of a year to measure the occurrence of an educational event: college access. By building a series of discrete-time survival analyses, this study focused on exploring the effect of Internet access and computer use for educational purposes on accessing college. Grounded on our findings on the access to generic colleges, future research could build a competing risk model (Allison, 2010) to investigate more specific roles of ICT uses on attending different types of colleges, for example two-year or four-year institutions, among the various racial and linguistic groups, considering potential disparities at selective colleges (ED Data Express, 2018).

\section{References}

Akerhielm, K., Berger, J., Hooker, M., \& Wise, D. (1998). Factors related to college enrollment. Final report. NJ: Mathtech.

Allison, P. D. (2010). Survival analysis using SAS: A practical guide. SAS Institute.

Aud, S., Fox, M. A., \& Kewal Ramani, A. (2010). Status and Trends in the Education of Racial and Ethnic Groups (NCES 2010-015). U.S. Department of Education, National Center for Education Statistics. Washington, DC: U.S. Government Printing Office.

Barra, C., \& Zotti, R. (2017). Investigating the human capital development-growth nexus: Does the efficiency of universities matter? International Regional Science Review, 40, 638 - 678. https://doi.org/10.1177/016 0017 615626215

Barrow, L., Brock, T., \& Rouse, C. E. (2013). Postsecondary education in the United States: Introducing the issue. The Future of Children, 23, 3 - 16. https://www.jstor.org/stable/23409486

Bozick, R., \& DeLuca, S. (2005). Better late than never? Delayed enrollment in the high school to college transition. Social Forces, 84, 527 - 550. https://doi.org/10.1353/sof.2005.0089. 
Brannelly, L., Lewis, L., \& Ndaruhutse, S. (2011). Higher education and the formation of developmental elites: A literature review and preliminary data analysis. DLP Research Paper, 10.

Brown, M. G., Wohn, D. Y., \& Ellison, N. (2016). Without a map: College access and the online practices of youth from low-income communities. Computers \& Education, 92, 104 - 116. https://doi.org/10.1016/j.compedu. 2015.10.001

Cahalan, M., Perna, L. W., Yamashita, M., Wright, J., \& Santillan, S. (2018). Indicators of Higher Education Equity in the United States: 2018 Historical Trend Report. Pell Institute for the Study of Opportunity in Higher Education.

Carnevale, A. P., Smith, N., \& Strohl, J. (2013). Recovery: Job growth and education requirements through 2020. Washington, DC: Georgetown Center on Education and the Workforce.

Daun-Barnett, N., \& Das, D. (2010). College access and the web-based college knowledge strategy: Analysis of the Know How 2 Go campaign. Enrollment Management Journal, 4, 42-65.

Daun-Barnett, N., \& Das, D. (2013). Unlocking the potential of the Internet to improve college choice: a comparative case study of college-access Web tools. Journal of Marketing for Higher Education, 23, 113 - 134. https://doi.org/10.1080/08841241.2013.805708

Davison, E. L., \& Cotten, S. R. (2009). Connection Disparities: The Importance of Broadband Connections in Understanding Today's Digital Divide. In E. Ferro, Y. K. Dwivedi, J. R. Gil-Garcia \& M. D. Williams (ed.), Handbook of Research on Overcoming Digital Divides: Constructing an Equitable and Competitive Information Society: Constructing an Equitable and Competitive Information Society (pp. 346-358). Hershey, PA: IGI Global. doi: 10.4018/978-1-60566-699-0.ch019

Dettling, L. J., Goodman, S., \& Smith, J. (2018). Every little bit count: The impact of high-speed internet on the transition to college. Review of Economics and Statistics, 100, 260 - 273. https://doi.org/10.1162/REST_a_0 0712

Drain, T. S., Grier, L. E., \& Sun, W. (2012). Is the growing use of electronic devices beneficial to academic performance? Results from archival data and a survey. Issues in Information Systems, 13, 225 - 231.

Dyce, C. M., Albold, C., \& Long, D. (2013). Moving from college aspiration to attainment: Learning from one college access program. The High School Journal, 96, 152 - 165.

ED Data Express. (2018). State graduation rates. Retrieved from https://eddataexpress.ed.gov/state-tables-main.cfm

Engle, J. (2007). Postsecondary access and success for first-generation college students. American Academic, 3,25 48.

Eynon, R., \& Malmberg, L. E. (2011). A typology of young people's Internet use: Implications for education. Computers \& Education, 56, 585 - 595. https://doi.org/10.1016/j.compedu.2010.09.020

Fairlie, R. W., \& Bahr, P. R. (2018). The effects of computers and acquired skills on earnings, employment and college enrollment: Evidence from a field experiment and California UI earnings records. Economics of Education Review, 63, 51 - 63. https://doi.org/10.1016/j.econedurev.2018.01.004

Freeman, B. (2012). Using digital technologies to redress inequities for English language learners in the Englishspeaking mathematics classroom. Computers \& Education, 59, 50 - 62. https://doi.org/10.1016/j.compedu. 2011.11.003

Horn, L. J. (1998). Confronting the odds: Students at risk and the pipeline to higher education. NCES Report No. 98094. Washington, DC: U.S. Department of Education.

Hosmer, D., Lemeshow, S., \& May, S. (2008). Applied survival analysis: Regression modelling of time to event data (2nd ed.). New York: Wiley-Interscience.

Ingels, S. J., Pratt, D. J, Alexander, C. P., Jewell, D. M., Lauff, E. Mattox, T. L., \& Wilson, D. (2014). Education Longitudinal Study of 2002 Third Follow-up Data File Documentation (NCES 2014-364). National Center for Education Statistics, Institute of Education Sciences. Washington, DC: U.S. Department of Education. Retrieved on July 12, 2019 from http://nces.ed.gov/pubsearch.

Johnson, A. (2019). The effects of English learner classification on high school graduation and college attendance. AERA Open, 5. https://doi.org/10.1177/2332858419850801

Kanno, Y., \& Cromley, J. G. (2013). English language learners' access to and attainment in postsecondary education. Tesol Quarterly, 47, 89 - 121. https://doi.org/10.1002/tesq.49

Kenayathulla, H. B. (2013). Higher levels of education for higher private returns: New evidence from Malaysia. International Journal of Educational Development, 33, 380 - 393. https://doi.org/10.1016/j. ijedudev. 2012.05.008

Kewal Ramani, A., Zhang, J., Wang, X., Rathbun, A., Corcoran, L., Diliberti, M., \& Zhang, J. (2018). Student access to digital learning resources outside of the classroom (NCES 2017-098). U.S. Department of Education. 
Washington, DC: National Center for Education Statistics. Retrieved on June 22, 2019 from https://nces.ed.gov/pubsearch/pubsinfo.asp?pubid=2017098.

Kim, S. (2018a). ICT and the UN's sustainable development goal for education: Using ICT to boost the Math performance of immigrant youths in the US. Sustainability, 10, 4584. https://doi.org/10.3390/su10124584

Kim, S. (2018b). ICT for children of immigrants: Indirect and total effects via self-efficacy on Math performance. Journal of Educational Computing Research, 55, 1168 - 1200. https://doi.org/10.1177/0735633117699954

Kim, S., \& Chang, M. (2008). Computer use in diverse learning contexts in ELS 2002: Gender, race and learnercenteredness effects and implications. The Journal on School Educational Technology, 3, 55 - 65.

Kim, S., Chang, M., Singh, K., \& Allen, K. (2015). Patterns and factors of high school dropout risks of racial and linguistic groups. The Journal of Education for Students Placed at Risk, 20, 336 - 351. doi: $10.1080 / 10824669.2015 .1047019$

Klasik, D. (2012). The college application gauntlet: A systematic analysis of the steps to four-year college enrollment. Research in Higher Education, 53, 506 - 549. https://doi.org/10.1007/s11162-011-9242-3

Lee, K., Tsai, P. S., Chai, C. S., \& Koh, J. H. L. (2014). Students' perceptions of self-directed learning and collaborative learning with and without technology. Journal of Computer Assisted Learning, 30, 425 - 437. https://doi.org/10. 1111/jcal.12055

Lavrinovicha, I., Lavrinenko, O., \& Teivans-Treinovskis, J. (2015). Influence of education on unemployment rate and incomes of residents. Procedia-Social and Behavioral Sciences, 174, 3824 - 3831. https://doi.org/10.1016/ j.sbspro.2015.01.1120

Luu, K., \& Freeman, J. G. (2011). An analysis of the relationship between information and communication technology (ICT) and scientific literacy in Canada and Australia. Computers \& Education, 56, 1072 - 1082. https://doi.org/10. 1016/j. compedu.2010.11.008

Ma, J., Pender, M., \& Welch, M. (2016). Education Pays 2016: The Benefits of Higher Education for Individuals and Society. Trends in Higher Education Series. College Board.

Martin, A. J. (2010). Should students have a gap year? Motivation and performance factors relevant to time out after completing school. Journal of Educational Psychology, 102, 561 - 576. doi:10.1037/a0019321.

Martinez, M. A., Cortez, L. J., \& Saenz, V. B. (2013). Latino parents' perceptions of the role of schools in college readiness. Journal of Latinos and Education, 12, 108 - 120. https://doi.org/10.1080/15348431.2012.745402

Martinez, M. A., Vega, D., \& Marquez, J. (2019). Latinx students' experiences with college access and preparation at college preparatory charter schools. Journal of Latinos and Education, 18, 28 - 41. https://doi.org/10.1080/ 15348431.2017 .1418353

Martinez, M. A., \& Welton, A. D. (2014). Examining college opportunity structures for students of colour at high"minority," high-poverty secondary schools in Texas. Journal of School Leadership, 24, 800 - 841. https://doi.org/10. 1177/105268461402400501

Mossberger, K., Tolbert, C. J., \& Hamilton, A. (2012). Broadband adoption| measuring digital citizenship: Mobile access and broadband. International Journal of Communication, 6, 2492 - 2528.

National Center for Education Statistics. (2016). Digest of education statistics. Retrieved from https://nces.ed.gov/ programs/digest/d15/tables/dt15_302.10.asp.

National Telecommunications and Information Administration. (2016). First Look: Internet Use in 2015. Retrieved from https://www.ntia.doc.gov/blog/2016/first-look-internet-use-2015.

National Telecommunications and Information Administration. (2018). Internet Use at Home. Retrieved from https://www.ntia.doc.gov/data/digital-nation-dataexplorer\#sel=homeInternetUser\&demo=race\&pc=prop\& disp=chart

Niu, S., \& Tienda, M. (2013). Delayed enrollment and college plans: Is there a postponement penalty? Journal of Higher Education, 84, 1 - 27. https://doi.org/10.1080/00221546.2013.11777276

Organization for Economic Cooperation and Development. (2017). OECD Digital Economy Outlook 2017. Paris: OECD Publishing. Retrieved from https://dx.doi.org/10.1787/9789264276284-en

Organization for Economic Cooperation and Development. (2017). Education at a Glance 2017. Paris: OECD Publishing. Retrieved from https://dx.doi.org/10.1787/9789264276284-en.

Papanastasiou, E. C., \& Ferdig, R. E. (2006). Computer Use and Mathematical Literacy: An analysis of existing and potential relationships. Journal of Computers in Mathematics and Science Teaching, 25, 361 - 371.

Pearce, K. E., \& Rice, R. E. (2013). Digital divides from access to activities: Comparing mobile and personal computer Internet users. Journal of Communication, 63, 721 - 744. https://doi.org/10.1111/jcom.12045

Perna, L. W. (2005). The key to college access: Rigorous academic preparation. In W. G. Tierney, Z. B. Corwin, \& J. E. Colyar (Eds.), Preparing for college: Nine elements of effective outreach (pp. 113-134). Albany, NY: SUNY Press. 
Perna, L. W. (2006). Understanding the relationship between information about college prices and financial aid and students' college-related behaviors. American Behavioral Scientist, 49, 1620 - 1632. doi:10.1177/0002764 206289144.

Perna, L. W. (2015). Reimagining the Study of Higher Education. Educational Researcher, 44, 311 - 312. https://doi.org/10.3102/0013189X15593912

Rashid, T., \& Asghar, H. M. (2016). Technology use, self-directed learning, student engagement and academic performance: Examining the interrelations. Computers in Human Behavior, 63, 604 - 612. https://doi.org/10. 1016/ j.chb.2016.05.084

Singer, J. D., \& Willett, J. B. (2003). Applied longitudinal data analysis: modelling change and event occurrence. Oxford, New York: Oxford University Press.

Smythe, A. (2019). Labor market conditions and racial/ethnic differences in college enrollment. Journal of Economics, Race, and Policy, 1 - 11. https://doi.org/10.1007/s41996-019-00030-4

Snyder, T. D., de Brey, C., \& Dillow, S. A. (2019). Digest of Education Statistics 2017 (NCES 2018-070). National Center for Education Statistics, Institute of Education Sciences. Washington, DC: U.S. Department of Education.

Sumuer, E. (2018). Factors related to college students' self-directed learning with technology. Australasian Journal of Educational Technology, 34, 29 - 43. https://doi.org/10.14742/ajet.3142

Taylor, Z. W. (2018). " Now you're competing": How historically Black colleges and universities compete (and don't) on the Internet. International Journal of Educational Technology in Higher Education, $15,28$. https://doi.org/10.1186/s41239-018-0111-4

Tierney, W. G., \& Jun, A. (2001). A university helps prepare low income youths for college: Tracking school success. Journal of Higher Education, 72, 205 - 225. https://doi.org/10.1080/00221546.2001.11778878

Thomas, S. L., Heck, R. H., \& Bauer, K. W. (2005). Weighting and adjusting for design effects in secondary data analyses. New Directions for Institutional Research, 2005, 51 - 72. https://doi.org/10.1002/ir.155

Van Deursen, A. J., \& Van Dijk, J. A. (2015). Toward a multifaceted model of Internet access for understanding digital divides: An empirical investigation. The Information Society, 31, 379 - 391. https://doi.org/10.1080/01972243. 2015.1069770

Vega, D., Moore III, J. L., \& Miranda, A. H. (2015). In their own words: Perceived barriers to achievement by African American and Latino high school students. American Secondary Education, 43, 36 - 59.

Venegas, K. M. (2006). Internet inequalities: Financial aid, the Internet, and low-income students. American Behavioral Scientist, 49, 1652 - 1669. https://doi.org/10.1177/0002764206289147

Waryoba, F. D. (2017). Education and Economic Growth: Is Tertiary Education for all Workers Optimal? Academic Journal of Economic Studies, 3, 29 - 34.

White House Press Secretary Fact Sheet. (2010, February 22). Preparing students for success in college and the workforce. Retrieved from http://www.whitehouse.gov.gate.lib.buffalo.edu/sites/default/files/rssviewer/ education_standard_factsheet.pdf.

Wohn, D. Y., Ellison, N. B., Khan, M. L., Fewins-Bliss, R., \& Gray, R. (2013). The role of social media in shaping first-generation high school students' college aspirations: A social capital lens. Computers \& Education, 63, 424 - 436. https://doi.org/10.1016/j.compedu.2013.01.004 